\title{
Task-based Approach to Teaching English for Tour Guiding Students in EFL Context
}

\author{
Gusti Astika \\ Universitas Satya Wacana, Salatiga
}

\begin{abstract}
This paper describes a task-based approach to teaching English using an authentic material obtained from a guided tour. It begins with a brief discussion on forms-focused instruction, then follows a discussion on meaning-focused and form-focused instruction. This paper also cites theoretical framework and research to justify the implementation of task-based language teaching. It argues that task-based language teaching needs to be modified to accommodate the needs of teaching the language in EFL contexts. At the end of the paper, a procedure is proposed for the implementation of task-based language teaching using a sample material from tour guiding.
\end{abstract}

Key words: forms-focused instruction, meaning-focused instruction, taskbased language teaching, task, task planning

Many high school graduates who have studied English (as a FL) leave school unable to communicate in it. Many students acquire a small number of formulaic phrases, but are unable or too shy to use them. Although many of them pass their examinations successfully, they cannot use their knowledge in conversations.

One reason why this happens is because much of their exposure to English lessons consists of written language at the sentence level. They are used to reading textbook exercises and hearing carefully scripted dialogues. In general, exposure to real spoken interaction in English in the classroom is very minimum, except that used by the teacher. 
This is not to say that classroom instruction is useless. Indeed there is much evidence to suggest that instruction does help. In Long (1988:136) for example, instruction was found to have a positive effect on SLA process, on the rate learners acquire the language. However, formal instruction alone is rarely a sufficient condition for learning a language.

Learners often go on making the same error even after being corrected many times. Sometimes students seem to master grammar points successfully in a lesson and get it right when doing an exercise on it. But they often fail to use it correctly when expressing themselves freely. In other words, this temporary mastery seems to work well when they are paying conscious attention to form but not when they are trying to communicate and paying attention to meaning. Then, practice activities, such as drilling a particular language pattern, is not necessarily helpful especially when it comes to communication. This is one limitation of forms-focused instruction in teaching the language.

\section{FORMS-FOCUSED OR GRAMMAR-BASED LANGUAGE TEACH.} ING

Focus on forms refers to instruction that seeks to isolate linguistic forms in order to teach and test them one at a time (Long, 1991). It is found when language teaching is based on a structural syliabus. Unlike a taskbased course design, a design based on forms starts with the language to be taught as units of analysis. The teacher or syllabus designer divides the language into structural units such as sentence patterns, notions, functions, stress and intonation patterns and so on. These structural items are taught one at a time, in a sequence on the bases of frequency or difficulty though the sequencing is mostly intuitively inferred. Learners are typically encouraged to master each linguistic item one at a time as it is taught. Classroom activities commonly take the form of explicit grammar rules, repetition of models, memorization of short dialogues, linguistically simplified text, transformation exercises, explicit negative feedback or error correction, and display questions and answers. Long (1997) calls this lesson 'a focus on forms'. This lesson tends to be dry, consisting primarily of work on the linguistic items, which students are expected to master one at a time.
This structural approach to teaching the language has been the subject of criticism because it is not based on needs analysis to identify what a particular group of learners need. Needs analysis is an important element in a syllabus design. Teaching language elements one at a time in an intuitively sequential order does not take into account the fact that language learning processes do not happen sequentially in the way language items are taught. Many research findings show that learning new words or rules is not a one-time event, and that learners pass through different developmental stages. As Rutherford (1988) noted, SLA is not a process of accumulating entities in a linear fashion and yet, that is precisely what a structural syllabus tries to teach.

The research by Ellis and Lightbown (1983) also shows that acquisition sequences do not reflect instructional sequences. They found that acquisition of German word order was determined by internal mechanisms rather than by input. Lightbown's study (1983) on the use of grammatical morphemes by young French speakers receiving formal ESL instruction and aspects of the language they heard in the classroom suggests that there is no direct relationship between the frequency with which certain forms appear in the classroom and the frequency or accuracy of use of these forms in the learner's language at the same point in time.

These studies show that language acquisition is not linear like the order of teaching sequence and what is learned is not sequentially the same as how it is taught. It does not follow that instruction does not have a place in learning. Instruction may serve to speed up acquisition and also may help to achieve a higher level of mastery but "the idea that what you teach is what they learn, and when you teach is when they learn it is simplistic and wrong' (Long, 1997:4).

\section{MEANING-FOCUSED INSTRUCTION OR COMMUNICATIVE LANGUAGE TEACIING}

As a response to the problems of teaching with the focus of forms, language teaching focuses on meaning. The starting point is not the language structure but the learner and leaming processes. LI and L2 acquisi- 
tion is thought to be essentially similar. So, if relatively similar conditions in $L 2$ learning are created and resemble those conditions in L1 learning, it should be sufficient for L2 learning to take place. Unfortunately, this is not the case. Accordingly, lessons which focus on meaning, are purely communicative. Learners are presented with comprehensible samples of L2 use in a meaningful context, for example, in the form of content-based lessons, or lessons that are interesting and relevant. Crammar rules are learned inductively from exposure to comprehensible input.

However, though the meaning-focused instruction sounds promising, it is not without limitations. Many researchers have found increasing evidence for the operation of maturational constraints, including sensitive periods in L2 acquisition (Long, 1990). A number of studies suggest that older children, adolescents and adults regularly fail to achieve native-like levels in an L2 not because they lack opportunity, motivation or ability, but because they have lost the opportunity to acquire native-like ability due to age-related factors and loss of neural plasticity in earlier childhood. Long (1990) argues that if this is the case, then it will be insufficient for later L2 learning simply to recreate the conditions for $L 1$ acquisition in $L 2$ classrooms although instruction places primary emphasis on communication. This approach, too, is not without flaws.

Limitations of communicative ESL to promote high level of accuracy in learners are discussed in Williams (1995:13). He says that if the emphasis of teaching and learning is on fluency and communication, it may not encourage leamers to pay attention to the structure. Communication in the classroom may proceed quite successfully but students may show a lot of grammatical difficulties. Then, some attention to teach grammatical form should be necessary. The need to focus on language structure is ever more pronounced in contexts where learners do not have access to develop their grammatical ability outside the classroom such as that in EFL settings. Therefore, Long's proposal on 'form-focused' instruction could balance the need for both grammatical and communicative ability. This is discussed in the section below.

\section{FORM-FOCUSED INSTRUTCTION}

According to Long (1997), focus on form (without s) involves "alternating in some principled way between a focus on meaning and a focus on form', or 'a range of pedagogical interventions that seek to attract and direct learners' attention to specific formal aspects of the language code in the context of meaningful language use' (Ortega, 1999: 110). This is done when the learners are engaged in a communicative activity within a taskbased teaching. If a grammar problem arises, the teacher should deal with it in such a way that the learners' attention is focused only to that particular problem, and then, continue with the communicative activity.

Focus on form is, therefore, learner-controlled. It is carried out when a student has a communication problem during the activity due to incomplete understanding of a particular form or function or when he or she is having difficulties in understanding inputs from other students. The purpose of drawing learners' attention to a particular form is to induce what Schmidt (1993) calls 'noticing'. Focus on form instruction is an alternative to both focus on forms and focus on meaning ( $L o n g, 1991$ ). As mentioned in the preceding section, the form-focused instruction is carried out within a task-based teaching. This is discussed in the following section.

\section{TASK-BASED LANGUAGE TEACHING}

Task-based language teaching is based on the view of language as a social means to carry out communication purposes. Long and Crookes (1992) say that the rationale of a task-based syllabus derives from principles of human learning in general and second language learning in particular. The units of analysis in task-based language learning are not based on linguistic forms but on concepts of task (p.27). In addition, they mention that taskbased language teaching also derives from SLA research indicating that formal instruction has some impact on the use of some learning strategies, and that formal instruction clearly improves the rate of learning (p.42). This may indicate the importance of drawing learners' attention to those formal aspects to facilitate leaming. 
Research on task shows that leamers are involved in negotiation of meanings during task activities where they receive the kind of inputs that are necessary to help facilitate learning and acquisition. It follows that if learning is facilitated through task fulfillment activities, tasks should form the basis of syllabus and teaching. Research on tasks also shows that language learners employ different learning strategies through different kinds of classroom learning tasks. It is assumed that learning strategies can be taught. Oxford and Nyikos (1989) suggest that,

'students should be encouraged to experiment with a great variety of strategies and to apply them to tasks which promote creative, communicative learning and ... the language program should take into account learner's needs, including the need to gain self-control and autonomy through strategy use' (p.297)

One aspect of learning strategy that relates to teaching principles is interaction strategies. Bejarano et.al (1997) identify two types of interaction strategies: modified interaction strategy and social interaction strategy. The modified interaction strategy consists of strategies that enable interlocutors to modify their speech in order to facilitate comprehension of messages, such as checking for comprehension, appealing for assistance, giving assistance, and repairing. The social interaction strategies are those strategies that are necessary for maintaining the flow of conversation or interaction between the speaker and hearer, such as elaboration, responding, seeking information or opinion, paraphrasing or facilitating the flow of conversations. In a task-based instruction, learners could develop these leaming strategies, a necessary feature of interaction.

\section{DEFINING TASKS}

The word 'task' has been used to label various activities; everyday life activities and classroom language activities such as grammar exercises, practice activities and role-plays. The definitions below are taken from Nunan (1989).

A task is: "a piece of work undertaken for oneselif or for others, freely or for some reward. Thus, examples of tasks include painting a fence, dressing a child, filling out a form...In other words, by 'task' is meant the hundred and one things people do in everyday hife, at work, at play, and in be tween' (Long, 1986:89).

Long takes examples of the kind of work from everyday life experience to define tasks, so his definition is non-linguistic because they refer to non-language related activities that take place outside classroom environments.

Richards and Weber (1986) take a different perspective to define tasks. They say that a task is:

'an activity of action which is carried out as the result of processing or understanding language. For example, drawing a map while listening to a tape, listening to an instruction and performing a command, may be referred to as tasks. Tasks may or may not involve the production of language. A task usually requires the teacher to specify what will be regarded as successful completion of the task. The use of a variety of different kinds of tasks in language teaching is said to make language teaching more communicative.since it provides a purpose for a classroom activity which goes beyond the practice of language for its own sake' (Richards and Weber, 1986:289).

This definition has a pedagogic perspective. A task is defined in terms of teaching in the classroom setting referring to the kinds of activities that learners do in the classroom. It is different from Long's definition in terms of the setting where a task is completed. The common feature of both definitions is that they both involve the use of language for communication purposes with the focus on meanings, not linguistic forms or structures.

The definition of tasks that Nunan uses also focuses on meaning rather than form, as he puts it:

Communicative task is a piece of classroom work which involves learners in comprehending, manipulating, producing or interacting in the target language while their attention is principally focused on meaning rather than form' (Nunan, 1989:10). 
These definitions suggest that all tasks should have an outcome and that the outcome should be the result of some communication using the language. A task should have meaning, goal and activities (Skehan, 1998).

\section{CRITERIA FOR A TASK}

Skehan (1998) suggests that a task should fulfil the following criteria: a. meaning is primary

b. there is a goal which needs to be worked towards

c. the activity is outcome-evaluated

d. there is a real-world relationship

Thus, an activity that focuses on language forms alone cannot be considered as a task. For example, pattern drills on a particular structure. The primary focus is not on meaning and it does not happen in the real world. Tasks for classroom use could be developed according to the task's processing demands (Skehan, 1998) or distribution of information among different participants and how participants are expected to act on this information (Long, 1989).

Within the framework of task-based instruction, Fotos (1998) suggests that grammar should be taught implicitly by 'flooding' input with numerous usage, or by making the structures prominent through highlighting or some other physical treatment. The learners are expected to be able to notice, then process, linguistic structures, which have been introduced to them within communicative contexts. The 'attention focusing' and 'understanding' are related to Schmidt's (1990) claim that consciousness at the level of noticing the form of input is necessary to subsequent $L 2$ learning, and that consciousness at the level of rule understanding is strongly facilitative of later learning. The 'attention focusing' format in teaching is considered to facilitate learning because it causes learners to notice salient aspects of the structure being explained by the teacher or comprehending the explanation itself leads to understanding of the structure (Robinson, 1996).
Other researchers have suggested that learners could benefit from some type of explicit instruction prior to the task activity to help them activate their previous knowledge of the target structures, or to facilitate awareness of the forms they will encounter (Skehan, 1996). Explicit grammar instruction could be combined with communicative activities by giving learners short grammar lessons, which are then followed by communicative input containing instances of the instructed form. Again, the communicative activities are often followed by a teacher-led review of the target grammatical form, and feedback on errors (Ellis, 1995).

\section{TASK IMPLEMENTATION}

Since a task-based approach to language learning requires student commitment and involvement in the instructional process, it might be necessary to consider learner opinions of what they think enhances the learning process. This is important because students whose instructional expectations are not met may consciously or subconsciously question the credibility of instructional approach in cases where corrective feedback is not appropriately provided.

Kern (1995) supports the view that learners beliefs about learning are important to language learning in institutional settings because understanding their beliefs could help teachers minimize the potential of expectation conflicts occurring in the class. This conflict may contribute to student ${ }^{\prime}$ lack of motivation and frustration. Schulz's (1996:348) study on students" attitudes towards error correction indicated that they had favorable attitudes toward a focus on forms in L2/FL language learning. He speculates that (1) Student opinions toward feedback on forms may be based largely on a myth regarding the usefulness of grammar study, passed on from generation to generation of FL/L2 learners. (2) Student opinions may be strongly influenced by the grammar-based curriculum and discrete point testing methods that are still practiced in many FL classrooms. This may have convinced learners that a focus on forms is what language learning requires. (3) Student opinions may be actually based on personal experiences that have convinced them their learning is enhanced by rule awareness and corrective feedback on forms. 
Leamers' expectation of feedback to their language learning is not uncommon. They view the teacher as someone who has the knowledge to provide feedback and this attitude is very strong in FL learning where the classroom is the only appropriate place where students can expect to get reedback. Therefore, feedback is an inevitable practice in classroom interactions. As Chaudron (1988) points out:

the primary role of language teachers is often considered to be the provision of both error correction, a form of negative feedback, and positive sanctions or approval of learners' production. In most other social interactions, no one participant is specified as having the automatic right to impose judgement on the other's behavior, especially linguistic behavior (p.132).

Corrective feedback may take different forms such as interrupt, provide, repeat etc., but Chaudron cautions that it is dangerous to assume that students would learn just because the teacher provides feedback on their errors during classroom interaction (p.152).

It may be necessary to make a balance between what students' expectation for feedback and how to realize it in a form-focused instruction as suggested by Long. Student's need for error correction is variably different from one another. Form-focused instruction may accommodate individual student needs for correction since form-focused work should be done incidentally when the need arises.

\section{THE ROLE OF PLANNING PRIOR TO TASK ACTIVITIES}

Before students are asked to complete a task, they may as well be given enough time to plan what they want to say or do. The importance for the roles of planning prior to task completion has been documented in many studies. Ellis (1987:111) for example, says that students will be able to use language forms if they are given time to plan and exercise the forms.

If that is the case, he argues, providing opportunities to plan their language should increase the likelihood of difficult forms being eventually acquired and used into their language during task activities. Crookes (1988) says that planned output pushes the students' language to its limits and thus facilitates second language acquisition processes. Skehan (1994, 1996, and 1998) views planning as a task condition that regulates cognitive load. The opportunity to plan before L2 tasks lessens communicative stress and enables leamers to free up attentional resources and redirect them toward a focus on form. Ortega's study (1999:132) on task planning shows that:

1. Under conditions of planning, adult non-native speakers of Spanish were able to produce significantly more fluent and complex language.

2. Opportunity to plan before an L2 speaking task can enhance learners' attention to form during pre task planning.

These results provide support for the claim that planning before performing an $\mathbf{L} 2$ task can promote a conscious focus on form, even when learners are not directed specifically to attend to language.

Loschky and Bley-Vroman (1993) propose that if a teacher wants to make progress, one has to use the 'necessary' condition; meaning that one needs to devise tasks which 'force' the use of a particular structure. In this way, they suggest, one obtains the benefits of a task-based approach. Fotos and Ellis (1991) also take this position. Results of their study demonstrated that learners were able to increase their knowledge of a difficult L2 rule by completing a grammar task through interaction with other learners. Learners were provided with grammar problems they must solve interactively in meaningful communication. Long (in press) takes a different approach to choosing tasks and task implementation. He derives real-world task from some kind of needs analysis. Then pedagogic tasks are designed but there is no attempt to base task activities on any particular structure. He argues that if a task is accessible and motivating to the students, they will engage in the task and this will facilitate their language development.

\section{TASK-BASED LANGUAGE TEACHING IN EFL CONTEXTS}

Form-focused instruction within a task-based approach suggests that feedback to students' language difficulties be given implicitly. The extent to which this approach works successfully may depend on subsequent availability of input in communication that contains particular language forms. 
Unlike L2 contexts where opportunities to use the language outside the classroom setting are accessible, a FL situation is deprived of such an access and the classroom is the only place where learners can practice the language and get feedback. Even within EFL classrooms, target language use may be very infrequent.

However, if the focus-on-form approach is modified in such a way to allow for formal practice on likely target forms necessary for task completion before the task activity, and then provide feedback on the most pervasive and 'communicatively damaging' language problems, then this approach may offer considerable hope. It should be pointed out that form-focused practice before the task should not follow the practice in the forms-focused instruction, which ignores the context of language. The form-fucused instruction here should be targeted towards increasing the awareness of whatever the necessary structures are needed for task completion activities.

So, instead of 'forcing' particular structures into a task (Loschky and Bley-Vroman, 1993, Fotos and Ellis, 1991), learners could be presented with authentic materials and then under the guidance of the teacher, the students are asked to study particular structures used in the materials. Then learners carry out the task. During the task work, learners' language problems are dealt with (focus-on form principle). Then, following the suggestion by Willis (1996), a language focus activity is carried out at the end of the task work. In an EFL setting, this is necessary because practice opportunities of practicing the language structures are not available outside the classroom.

\section{MATERIAL FOR TASK-BASED ACTIVITIES}

The sample material below follows what has been discussed in the preceding sections. It is a live commentary of a tour guide, audio-taped in the bus from the airport to a hotel in Bali. The guide was standing at the front of the bus, beside the driver. He had a microphone and the recording was done from the back section of the bus. The transcript was not an accurate, precise representation of the guide's commentary presentation as it did not indicate the points where the guide made pauses as the bus was going, duration of pauses, intonation markers, speed of delivery, etc. During the transcription, grammatical mistakes were not corrected. The commentary was transcribed as closely as possible as it was presented. The purpose was to provide students with an authentic commentary with all its limitations in terms of content and language.

\section{PROCEDURES}

\section{Pre-task}

Introducing the task:

One of the jobs of a tour guide is to meet tourists at the airport and then take them to a hotel. On the way to the hotel, the guide gives some general information such as the distance of the hotel from the airport, the facilities of the hotel, the things that tourists can and should not do. This information is given in a bus that takes them to the hotel.

\section{Task cycle}

a. The teacher asks students to form small groups of three or four. In the group they discuss things that tourists can do and should not do when they go out from the hotel and take a walk, or they can discuss what important places around the hotel those tourists should know. The students should make a list of things that tourists should know.

b. Each group presents the list to the class and the teacher writes them on the board so that everybody can read the list. A brief discussion can follow based on the list.

c. The teacher gives the handout (the guide's commentary) to the students. (Please note that the commentary has a lot of problems linguistically and this is not the main focus of the lesson.) Then in the same group, they are asked to make a list of things that the guide commented on.

d. Compare their list from the commentary and the one on the board and discuss the differences.

e. In the group, ask them to make a similar commentary. Pretend that 
they are taking a group of tourists to a hotel. They should include as many as they can the items in the list that they think relevant. They can divide the work among group members then compile them at the end, or they can work together as a group. At this point the teacher can move around the class to help students with language difficulties as they are writing their commentary.

f. When they finish writing the commentary, they are asked to prepare a presentation. They are given enough time to prepare. Each member should take turn to practice giving commentary in the group as a preparation for in-class presentation.

g. The students are asked to present the commentary in front of the class. The teacher acts as a chairperson selecting who will speak next. During each presentation, other students are asked to make notes of what items are commented on by the student guide. After each presentation, the teacher and the students may briefly give feedback on the content of the commentary such as items in their written preparation that did not get commented on.

\section{Language focus}

a. After the presentation stage, the teacher and students work on the real commentary by the guide. They identify and discuss the language features that are used in the commentary, such as common phrases, verb tenses, tourist-related vocabulary, pragmatic features, etc.

b. Then follows brief practice of those language features under the teacher's guidance.

c. For homework, each group is asked to edit and revise their written commentary for submission on the following lesson.

\section{CONCLUSION}

A task-based language teaching with modified form-focused instruction is another pedagogical alternative for teaching the language in EFL contexts. Unlike the forms-focused approach, the form-focused in this dis- cussion integrates linguistic aspects before and after task activities in meaningful contexts within a particular task. Language knowledge is a means to the successful completion of task demands at every stage of task cycles, not an end in itself as commonly practiced in the forms-focused instruction.

\section{REFERENCES}

Bejarano, Y.et.al. 1997. The Skilled Use of Interaction Strategies: Creating a Framework for Improved Small Group Communicative Interaction in the Language Classroom. System: 25(2):203-214.

Chaudron, C. 1988. Second Language Classrooms: Research on Teaching and Learning. Cambridge University Press.

Crookes, 1988. Planning, Monitoring, and Second Language Development: A Review (Technical Report NO.4) Honolulu: University of Hawaii, Center for Second Language Classroom Research.

Ellis, R. 1995. Interpretation Tasks for Grammar Teaching. TESOL Quarterly, 29:87106

Ellis, R. 1987. Interlanguage Variability in Narrative Discourse: Style Shifting in the Use of the Past Tense. Studies in Second Language Acquisition, 9:1-20.

Fotos, S. 1998. Shifting the Focus from Forms to Form in the EFL Classroom. English Language Teaching Journal. 52(4):301-307.

Kern, R. G. 1995. Students' and Teachers' Beliefs about Language Learning. For eign Language Annals, 28:71-92.

Lightbown, P.M. 1983. Exploring Relations between Developmental and Instructional Sequences in L2 Acquisition. In H.G. Seliger and M.H. Long (Eds.), Classroom Oriented Research in Second Language Acquisition (pp. $217-$ 243). Rowley, MA: Newbury House.

Long, M.H. 1991. Focus on Form: A Design Feature in Language Teaching Methodology, In K. de Bot, R. Ginsbert, and C.Kramsch (Eds), Foreign Language Research in Cross-cultural Perspective (pp.39-52). Amsterdam: Benjamins.

Long, M.H. and Crookes, G. 1992. Three Approaches to Task-based Syllabus Design. TESOL Quarterly, 26(1):27-56.

Long, M.H. 1990. Maturational Constraints on Language Development. Studies in Second Language Acquisition, 12(3):251-286.

Long, H.M. 1988. Instructed Interlanguage Development. In L. Beebe (Ed.), Issues in Second Language Acquisition: Multiple Perspectives (pp. 115-141). Rowley, MA: Newbury House. 
Long, H.M. 1997. Focus on Forms in Task-based Language Teaching. http:/l ericaenet.

Long, M.H. In Press. Task-based Language Teaching. Oxford: Blackwell

Loschky, L. and Bley-Vroman, R. 1993. Grammar and Task-based Methodology. in G. Crookes and S. Gass (Eds.), Tasks and Language Learning: Integrating Theory and Practice (pp.123-167). Clevedon, Avon: Multilingual Matters.

Nunan, D. 1989. Designing Tasks for Communicative Classroom. New York: Cambridge University Press.

Ortega, L. 1999. Planning and Focus on Form in L2 Oral Performance. Studies in Second Language Acquisition, $21,109-148$.

Oxford, R.L. and Nyikos, M. 1989. Variables Affecting Choice of Language Learning Strategies by University Students. The Modern Language Journal, 73 : $291-300$.

Robinson, P. 1996. Learning Simple and Complex Second Language Rules Under Implicit , Incidental, Rule Search and Instructed Conditions. Studies in Second Language Acquisition, 18: 27-68.

Rutherford, W. 1988. Second Language Grammar: Teaching and Learning. London: Longman.

Schulz, R.A. 1996. Focus on Form in the Foreign Language Classroom: Students' and Teachers' Views on Error Correction and the Role of Grammar. Foreign Language Annals, 29(3):343-364.

Schmidt, R.W. 1993. Interaction, Acculturation, and the Acquisition of Communicative Competence. A Case Study of an Adult. In N. Wolfson and E. Judd (Eds.): Sociolinguistics and Second Language Acquisition (pp.137-174). Rowley, MA: Newbury House.

Skehan, P. 1994. Second Language Acquisition Strategies, Interlanguage Develop ment and Task-based Leaming. In M.Bygate, A. Tonkyn, and E. Williams (Eds.), Grammar and the Language Teacher (pp.175-199). New York Prentice Hall.

Skehan, P. 1996. A Framework for the Implementation of Task-based Instruction. Applied Linguistics, 17:38-62.

Skehan, P. 1998. A Cognitive Approach to Language Learning. Oxford: Oxford University Press.

William, J 1995. Focus on Form in Communicative Language Teaching: Research Findings and the Classroom Teacher. TESOL Journal 4:12-16.

Willis, J. 1996. A Framework for Task-based Learning. Essex Longman

\section{Appendix}

\section{The Handout (Guide's Commentary)}

Good afternoon ladies and gentlemen, welcome to Bali, on behalf of the local agent, Garuda Orient Holiday, I am taking you and the local agent's name is Satriavi.

Ladies and Gentlemen, I am so sorry you were waiting a little bit long time because I waited for two people but they haven't come yet so my friend will handle them to the hotel.

Ladies and Gentlemen, I have taken your vouchers especially for transferring to the hotel and also from the hotel to the airport, and from hotel to hotel too. And also don't worry about it because we have taken it just for schedule of your time when you are leaving.

Let me introduce myself. My name Roso and there are two trainees, ya. And driver's name is Hada. And from here to your hotel is very a... not for a long time, it take only ten minute because your hotel is very close to the airport. And located in Sanur place or Sanur area, oh, sorry, in Kuta. Because I have taken you know, two people to Sanur, I forget.

Yes, Kuta is divided into four villages, and nearby airport name is Tuban and afterwards Kuta and the western part of Kuta is Legian and the other one is Seminyak. And your hotel is located in Kuta village. And Kuta is well known for its abbreviation of Kota Untuk Turis Australia. So Australians prefer to stay here to other places because there are many facilities of things. May be are you going to buy something or may be are you going to drink or may be are you going to have a... meal, it is very easy to get because it is the central place.

Ladies and Gentlemen, if are you going to do a... shopping may be, here you should bargain the price as much as you can. Especially if you want to buy something on the street, or may be on the beach, or may be on the small shop. But if you want to buy a... in department store or in supermarket, and also, you know, everything fixed price, ya.

Ladies and Gentlemen, so I think you used to drink a... from pipe water in your country, in our country, in Bali you should a... you know, 
drink mineral water. Please buy in your hotel or outside there will be many a... you know, shops or bars selling mineral water. Please don't try to buy mineral water; sorry don't drink pipe water because otherwise you will spoil your holiday because of Bali Belly. Because you used to drink pipe water in your country, I should remind you to buy mineral water.

Ladies and Gentlemen, so if you are going to change money you can do it inside your hotel or outside your hotel. A week ago your money is around five thousand rupiah per dollar, and now approximately four thousand three hundred rupiah, ya.

Ladies and Gentlemen, if are you going to change money you should remember or I remind you if are you going to change, you know, outside of your hotel, you should, you know, which one is the best or which one is better. Because you know, there are money changers, which offer very much, some money changers are illegal, and most money changers are legal one. So how to change money, you should read you know, the rate, no commission. So that you not charged ten percent or sometimes you know, you will be ripped off, because the calculator had been set up in the wrong number or something like that. Or sometimes you know, in the bundle of million rupiah, you know, original because the biggest money is fifty thousand rupiah, afterwards less one is twenty thousand rupiah, and then ten thousand, and after you know, five thousand and one thousand rupiah. Sometimes in the bundle of money of fifty thousand rupiah, sometimes inside there is twenty thousand too. You should really check one by one. And also please recount with your calculator.

Ladies and Gentlemen, so if are you going to buy something there will be many people will offer you one dollar which actually not real one dollar. It is a trick of selling something. If you are interested to buy please negotiate as much as you can. And there will be many hustlers on the street, which offer you copy watches or something, copy of silver or copy of woodcarving also. If you buy the real one please buy in a department store, and also in a gallery of something like that.

Ladies and Gentlemen, this is your hotel, we call it Bali Bintang Hotel, so don't worry, your luggage is being transferred. Welcome to your hotel, Bali Bintang Hotel.
Ladies and Gentlemen, next hotel will be Santika Hotel. Also the next one is Kartika Plaza.

Ladies and Gentlemen, let me tell you what you should do in Bali, may be are you going to plait your hair, there will be many people who offer you plaiting your hair. Sometimes there will be five people and they will ask you for the price. So you are doing this, you should negotiate how much you should pay from the beginning to finish.

Over there is Kuta Square, where you can find department store and supermarket, called Matahari, not far from Santika, just turn left then, take approximately ten minutes to Kuta Square. And also you can find, you know, a... Kentucky Fried Chicken as you find in your country, but I think you sure prefer Indonesian cuisine to, you know, American.

Well, this is Santika Hotel and please enjoys your time. 